\title{
Biology of Grapsus grapsus (LinNaEus, 1758) (Brachyura, Grapsidae) in the Saint Peter and Saint Paul Archipelago, Equatorial Atlantic Ocean
}

\author{
A. S. Freire · M. A. A. Pinheiro · H. Karam-Silva • \\ M. M. Teschima
}

Received: 22 February 2010 / Revised: 18 June 2010 / Accepted: 13 July 2010 / Published online: 10 August 2010

(C) Springer-Verlag and AWI 2010

\begin{abstract}
Eleven expeditions were undertaken to the Saint Peter and Saint Paul Archipelago to study the reproductive biology of Grapsus grapsus, providing additional information on limb mutilation and carapace colour. MATURE software was used to estimate morphological maturity, while gonadal analyses were conducted to estimate physiological maturity. The puberty moult took place at larger size in males (51.4 mm of carapace length) than in females $(33.8 \mathrm{~mm})$, while physiological maturity occurred at a similar size in males $(38.4 \mathrm{~mm})$ and in females $(33.4 \mathrm{~mm})$. Above $50 \mathrm{~mm}$, the proportion of red males increased in the population, indicating that functional maturity is also related to colour pattern. Small habitat and high local population density contributed to the high rate of cannibalism. The low diversity of food items, absence of predators of large crabs and high geographic isolation are the determinants of unique behavioural and biological characteristics observed in the G. grapsus population.
\end{abstract}

Keywords Grapsus grapsus - Reproductive biology · Sexual maturity · Mutilation · Equatorial Atlantic Ocean

Communicated by H.-D. Franke.

A. S. Freire $(\bowtie) \cdot$ H. Karam-Silva $\cdot$ M. M. Teschima

Laboratório de Crustáceos/Plâncton,

Departamento de Ecologia e Zoologia, CCB/UFSC,

Campus Universitário Trindade, Florianópolis,

SC 88010-970, Brazil

e-mail: andreasfreire@yahoo.com.br

URL: http://www.crustaceoseplancton.ufsc.br

M. A. A. Pinheiro

Grupo de Pesquisa em Biologia de Crustáceos (CRUSTA),

UNESP/Campus Experimental do Litoral Paulista (CLP),

Praça Infante Dom Henrique, s/n, Parque Bitaru,

São Vicente, SP 11330-900, Brazil

\section{Introduction}

Within the Atlantic Ocean, the rocky shore crab Grapsus grapsus (LinnaEus, 1758) is very abundant on the Brazilian northern oceanic islands of the Saint Peter and Saint Paul Archipelago (SPSPA) (also known as Saint Paul's Rocks), at Rocas Atoll, and on Fernando de Noronha, while Grapsus adscensionis (OАBECK, 1765) occurs on various East Atlantic Island groups and along much of the West African coast (Hartnoll 2009). Morphological differences between these species are very minor (Manning and Chace 1990) and, according to Ratti (2004), would not justify the two species described. However, on the basis of the strong differences in the colouration patterns of the cephalothorax and pereiopods (Fig. 1), the absence of an evident connection via larval dispersal today and the differences in zoea 1 morphology (Guerao et al. 2001), we are inclined to accept them as different species. The status of the crabs from Trindade Island (500 miles off the eastern Brazilian coast) is yet to be determined (Hartnoll 2009). G. grapsus also occurs in the Caribbean Islands, on the eastern Pacific coast and islands (from Baja California to northern Chile) and on the Galapagos Islands. Despite the species' wide distribution and the great popularity of this crab among people visiting tropical paradises (it is known as the "Sally light foot" crab in English, "aratu" in Portuguese and "sayapa" in Spanish), there is little information available about its biology. Descriptions of intraspecific display, mating behaviour and gonopore morphology of G. grapsus were reviewed by Hartnoll (2009), but little additional information about their occurrence and general behaviour has been recorded since the first observations were made by Darwin in 1832 at Saint Paul's Rocks (c.f. Madeira 2008 and Freire et al. 2009). Reproductive and cannibalistic behaviour were described by Romero (2003). 
Fig. 1 a Grapsus grapsus (Linnaeus, 1758) in the Saint Peter and Saint Paul Archipelago; and b Grapsus adscensionis (Osbeck, 1765) on Ascension Island. Photo: a Maurício

Tavares, and b Richard Hartnoll
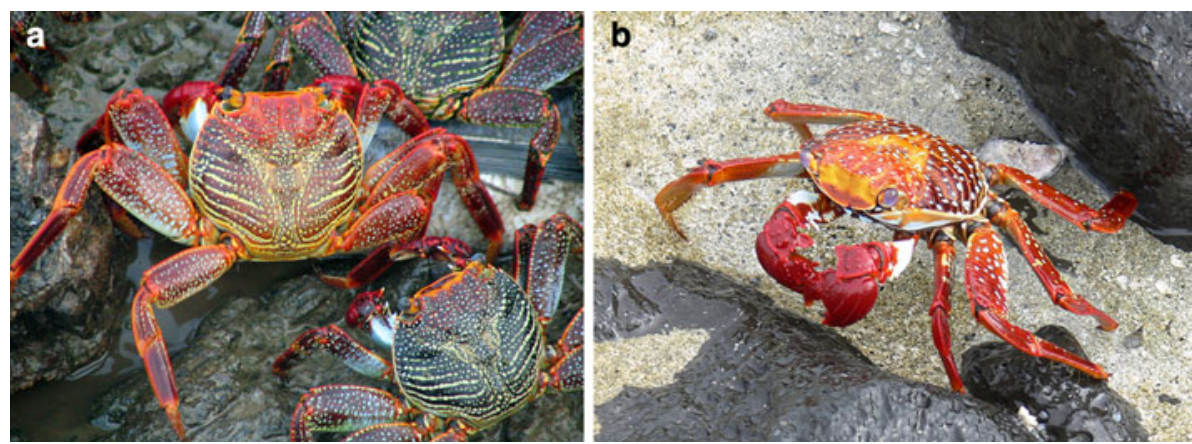

Due to the installation of a Brazilian scientific station on Saint Paul's rocks, it was possible to begin a broad investigation into Grapsus grapsus biology since 2003, focusing the research on larval ecology (Koettker et al. 2009), growth, abundance monitoring, intraspecific and interspecific interactions (Gianuca and Vooren 2007) and the present one about reproductive biology.

Determination of the size at which brachyuran crab species begins sexual activity is a key parameter to understanding its life cycle (Hartnoll and Gould 1988). Furthermore, estimation of size of sexual maturity is one of the most important information for planning management programmes (Pinheiro and Fransozo 1998), being marked by several morphological, physiological and behavioural changes, indicating the transition between phases (Hartnoll 1985).

The life cycle of $G$. grapsus, as with most brachyuran crabs, involves a planktonic larval phase (zoea), recruitment of megalopae and growth through instars. According to Hartnoll (1963), the relative growth of some brachyuran crustacean, like Majoidea crabs, can be characterized by three phases: immature, prepuberal and mature. These phases are separated by two important moults during ontogeny: prepuberty moult, in which immature crabs begin morphologic changes to become adults, and puberty moult, in which crabs acquire other morphological characters to become mature. The transition of the last juvenile instar to the first adult one is marked by a critical moult (the 'puberty moult'), which is accompanied by morphological changes (Hartnoll 2001). At the puberty moult, male chelae enlarge fast in relation to carapace width to be a better partner's hold, and females have an enlargement of their abdomen to protect the egg mass. These subtle changes in the relative proportion of these body parts make possible a precise estimative of the size at morphological maturity. Females of various crab species can and do mate (morphological maturity) before the ovaries mature, while males are required to present mature gonads (physiological maturity) (Schejter and Spivak 2005). The size at which morphological and physiological maturity are achieved is not necessarily the same; as a result, a determination of these different sizes at maturity in both sexes can be used to estimate functional maturity (Pinheiro and Fransozo 1998; Pinheiro and Fiscarelli 2001). Functional maturity is a broader concept that should also include mating ability, which depends on physiological, behavioural and morphological aspects (Corgos and Freire 2006). Sexual maturity studies about crabs are very common in the literature, especially in relation to species of economic importance, and also with grapsoids that play a key ecological role in their habitats (e.g. Flores et al. 2002; Flores and Paula 2002; Luppi et al. 2004).

The focus of this study is to estimate physiological and morphological maturity sizes of G. grapsus on Saint Paul's rocks, as well as to describe carapace colour patterns and their possible correlation with maturity. An evaluation of sex ratio and the incidence of mutilated individuals (limb autotomy and carapace injures) in the population are also presented. The findings reported here add new information to the few existing studies on the reproduction investment of tropical crab species (Hartnoll 2006), with possible use at management programmes.

\section{Materials and methods}

Study area

SPSPA $\left(00^{\circ} 56^{\prime} \mathrm{N}-29^{\circ} 22^{\prime} \mathrm{W}\right)$ is a group of 14 islets, with surrounding depths of 5,000 m, located near the Mid Atlantic ridge, around $80 \mathrm{~km}$ north of the Equator, $1,000 \mathrm{~km}$ from the Brazilian coast and $1,890 \mathrm{~km}$ from Senegal (Africa) (Fig. 2). It is one of the smallest and most isolated oceanic islands in the world (Feitoza et al. 2003). The main islets are separated by channels and a small inlet, with depths ranging from 4 to $25 \mathrm{~m}$. It receives waters from the east (South Equatorial Current) and west (Atlantic Equatorial Undercurrent) of the Atlantic Ocean (Edwards and Lubbock 1983). The area is a fishing ground for Scombridae (tuna fish), Carangidae and Exocoetidae (flying fish) (Vaske Júnior et al. 2006), with frequent observations of whale sharks and manta rays, and more than 50 species of reef fishes and many endemic species (Feitoza et al. 2003). 

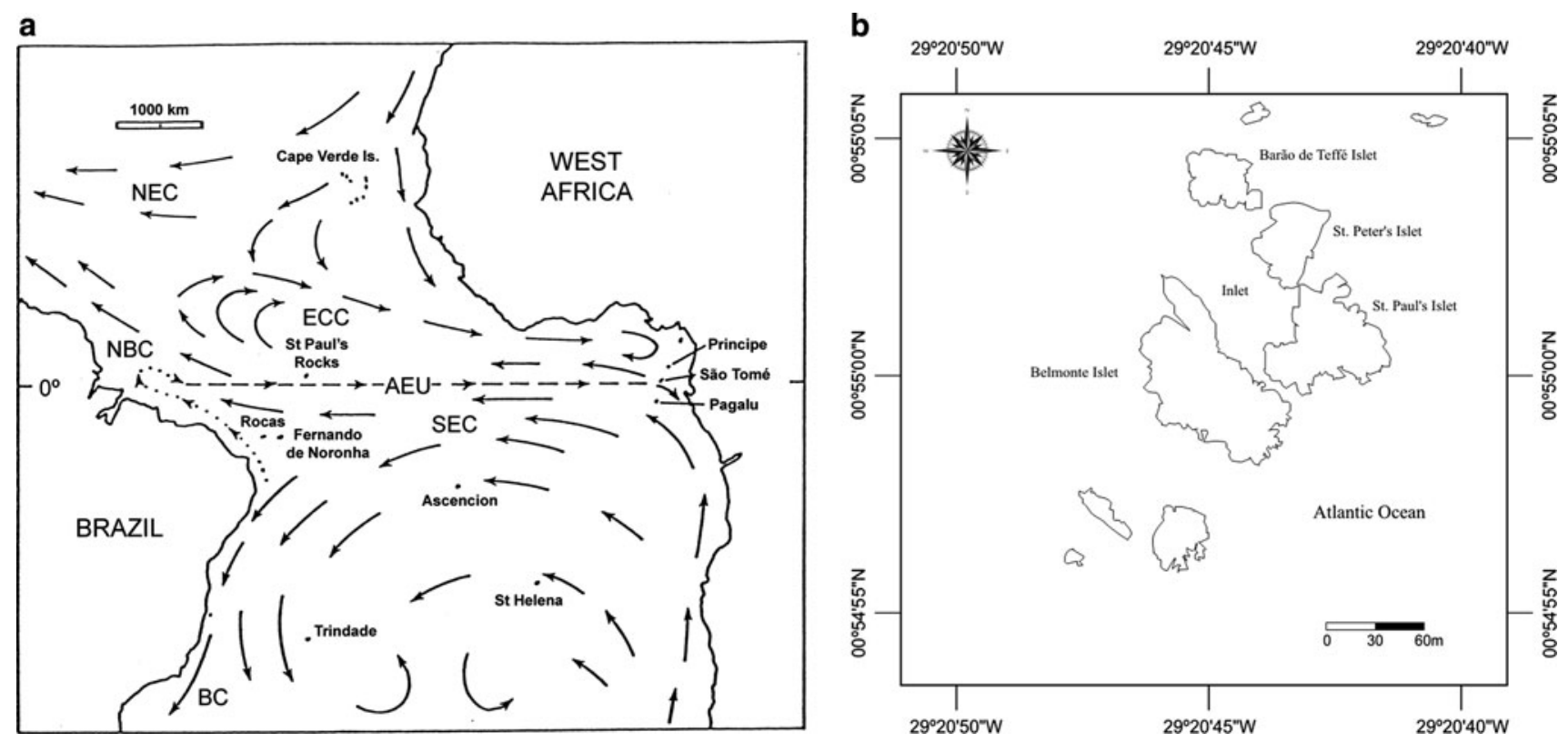

Fig. 2 a Position of the Saint Peter and Saint Paul Archipelago, and current circulation in the Atlantic Ocean (modified from Edwards and Lubbock 1983). ECC Equatorial counter current, $A E U$ Atlantic equa-

The area is recognized as a Brazilian Exclusive Economic Zone. The Brazilian Scientific Program for the SPSPA maintains a team of scientists there for 15-day period, assisted by fishermen, under extreme environmental conditions, such as rough waves, complete isolation and occasional seismic tremors. The research described here was concentrated at the Belmonte Islet, the largest islet, with an area of $500 \mathrm{~m}^{2}$. The emerged area of the Belmont Islet has a very irregular relief, where ocean waters fill the rocky pools mainly by the action of the waves. Tidal cycle had not been scientifically described in the area.

\section{Sampling strategies}

Crabs were spread out in the whole island, occupying different microhabitats as the rocky pools, rocky coast, rocky crevices, breeding and nesting sites of the booby Sula leucogaster (BODDAERT, 1783), under the scientific station and over the pier. The crabs were sampled randomly and manually, in all these microhabitats, using a $50-\mathrm{cm}^{2}$ net over the rocky floor or directly with the hands. Crabs were sampled during the day, especially in the morning, when the action of the waves was less intense. The crabs were immediately frozen in individual plastic bags and duly labelled. Samples were taken on 11 expeditions from February 2003 to May 2005, with the number of crabs/expedition limited by the Scientific Program.

During the laboratory analyses, the specimens were identified by sex and classified as males, non-ovigerous and torial undercurrent, SEC South Equatorial current, $B C$ Brazil current, $N B C$ North Brazilian current; and $\mathbf{b}$ the whole Archipelago showing the small inlet and Belmont Island

ovigerous females. The abdomen shape of the females was classified at three categories (triangular, triangular/round or round) (Fig. 6). The following measurements were taken with a vernier calliper $(0.05 \mathrm{~mm})$ : carapace width and length (CW and $\mathrm{CL}$, respectively), propodus length of the cheliped (PL), greatest width of the fifth female abdominal somite (AW) and length of first male gonopods (GL). Exemplars were dissected for gonadal development stage estimation by macroscopic analysis.

The relative growth of propodus and gonopod (males) and pleon (females) was studied using log-transformed data (see Pinheiro and Fransozo 1998, for details). The Snedecor's $F$ test $(a=0.01)$ was used to check whether one or two regression lines fit better the data. The biometric relations with best fit were used to describe growth changes between phases and estimate morphological maturity size in brachyurans, according to the procedures described by Pinheiro and Fransozo (1998). The data for each biometric relation establish a characteristic relative growth pattern and were processed using specific computer software: MATURE 1 (Somerton 1980) or MATURE 2 (Somerton and Macintosh 1983).

The physiological maturity of each sex was defined according to 3 macroscopic gonadal maturation stages (IM = immature; $\mathrm{DE}=$ developing; $\mathrm{MA}=$ mature, Table 1), considering shape, colour and gonadal size, modified from Pinheiro and Fransozo (2002) and Flores et al. (2002).

The size at which half the population of individuals are mature $\left(\mathrm{CW}_{50 \%}\right)$ was established by size distribution of each sex according to their gonadal maturation stage 
Table 1 Description of gonadal development stages used in macroscopic analyses of males and females of Grapsus grapus

\begin{tabular}{lll}
\hline Stage & Females & Males \\
\hline Immature & Not visible. Hepatopancreas highly developed & Not visible. Hepatopancreas highly developed \\
Developing & Small ovaries; light yellow to light orange & Vas deferens clearly visible; translucent to whitish \\
& Hepatopancreas developed & Hepatopancreas developed \\
Mature & Ovaries larger; orange to red with distinct oocytes. & Testes convoluted to enlarged and sinuous, white, \\
& Ovaries occupying most of the available cephalothorax space, & at lef the size of the hepatopancreas \\
& at least $1 / 2$ of the size of the hepatopancreas & \\
\hline
\end{tabular}

(IM = immature; $\mathrm{DE}=$ developing; $\mathrm{MA}=$ mature $)$ into 5-mm CW classes, by plotting the proportion of adult stages $(\mathrm{DE}+\mathrm{MA})$ in relation to juveniles (IM) for each CW class. The frequency of adults by size class was fitted for each sex using Galton's Ogive function $\left(y=1-e^{-\mathrm{AZ}}\right.$, with $\left.Z=x^{b}\right)$. An estimates of physiological maturation $\left(\mathrm{CW}_{50 \%}\right)$ was obtained for each sex by $\mathrm{CW}_{50 \%}=e^{[\ln [-\ln (1-0,5)]-\ln \mathrm{A}] / b}$ (Fonteles-Filho 1989).

The morphological and physiological maturity sizes to each sex were compared to verify a possible synchrony between these events and a possible establishment of functional maturity.

The colour pattern of the specimens was categorized into four groups: (1) Green: carapace green/dark green, with light yellow spots (Fig. 8); (2) Red leg: carapace dark green and pereiopods/chelipeds dark red; (3) Red frontal plate: carapace slight dark red (red in the frontal plate) and dark red legs; and (4) Red: carapace fully and bright red, yellow to white lines and spots and red legs (Fig. 1). The relation between colour pattern categories to $\mathrm{CW}$ was analysed graphically.

Crabs sampled randomly during 4 expeditions $(n=522)$ were used to register mutilation (injuries in the carapace as scars, holes, missing pereiopods and regeneration bourse). Frequency distribution of mutilated crabs and number of missing pereiopods were analysed by size (CW) class, and results obtained to each sex were compared by chi-square test (Zar 1998).

\section{Results}

A total of 705 crabs were captured (384 males and 321 females). Male size (CW) ranged from 14.2 to $69.5 \mathrm{~mm}$ $(39.9 \pm 12.1 \mathrm{~mm})$ and was significantly larger than female size $(P<0.05)$, which ranged from 9.1 to $57.3 \mathrm{~mm}$ $(35.9 \pm 11.1 \mathrm{~mm})$. The overall sex ratio was 1:0.9 MALE/ FEMALE $(P<0.01)$. The sex ratio did not differ significantly from $1: 1(P<0.05)$ in $70 \%$ of the months sampled. Ovigerous females $(n=94)$ ranged from 31.6 to $55.4 \mathrm{~mm}$ $(41.7 \pm 5.46 \mathrm{~mm})$ and recorded in all of samples, with reduced percentage $(<20 \%)$ during July and May (Table 2).
Table 2 Monthly abundance (number of individuals) of each sex and ovigerous condition, as well as monthly sex ratio at Saint Peter and Saint Paul Archipelago, Brazil

\begin{tabular}{|c|c|c|c|c|c|c|c|c|}
\hline \multirow[t]{2}{*}{ Months } & \multirow{2}{*}{$\begin{array}{l}\text { Male } \\
\text { total }\end{array}$} & \multicolumn{3}{|c|}{ Female } & \multirow[t]{2}{*}{ Total } & \multirow[t]{2}{*}{ OV\% } & \multicolumn{2}{|c|}{ Sex ratio } \\
\hline & & NO & $\mathrm{OV}$ & Total & & & $\mathrm{M}: \mathrm{F}$ & Sig \\
\hline Feb 2003 & 74 & 17 & 17 & 34 & 108 & 50.0 & $1: 0.5$ & * \\
\hline Apr & 34 & 17 & 7 & 24 & 58 & 29.2 & 1:0.7 & NS \\
\hline Jul & 41 & 18 & 3 & 21 & 62 & 14.3 & $1: 0.5$ & $*$ \\
\hline Nov & 25 & 24 & 7 & 31 & 56 & 22.6 & $1: 1.2$ & NS \\
\hline Mar 2004 & 26 & 17 & 7 & 24 & 50 & 29.2 & 1:0.9 & NS \\
\hline Aug & 29 & 18 & 6 & 24 & 53 & 25.0 & $1: 0.8$ & NS \\
\hline Nov & 53 & 31 & 27 & 58 & 111 & 46.6 & $1: 1.1$ & NS \\
\hline Jan 2005 & 35 & 42 & 14 & 56 & 91 & 25.0 & 1.1 .6 & * \\
\hline May & 38 & 33 & 5 & 38 & 76 & 13.2 & $1: 1$ & NS \\
\hline Jul & 22 & 17 & 1 & 18 & 40 & 5.6 & 1:0.8 & NS \\
\hline Total & 377 & 234 & 94 & 328 & 705 & 28.7 & $1: 0.9$ & NS \\
\hline
\end{tabular}

$\mathrm{NO}$ not ovigerous, $\mathrm{OV}$ ovigerous, $\mathrm{OV} \%$ percentage of ovigerous females in relation to total females

$* P<0.05$

Morphological maturity estimation

Allometric expressions, determination coefficients, allometric level and the results of Somerton's analyses are shown for each relationship, sex and categories in Table 3; Figs. 3 and 4.

MATURE 1 revealed three regressions for biometric relation $\mathrm{PL} \times \mathrm{CW}: \mathrm{CW}<28 \mathrm{~mm} ; 28 \leq \mathrm{CW}<51.4 \mathrm{~mm}$; and $\mathrm{CW} \geq 51.4 \mathrm{~mm}$. There was negative allometric growth before the prepuberty moult $(28 \mathrm{~mm})$ followed by positive growth until the puberty moult at $51.4 \mathrm{~mm}$. After the puberty moult, there was a huge increase in the allometric constant (1.19-1.82).

The same software revealed two regression lines for the relation $\mathrm{GL} \times \mathrm{CW}$, with inflection pointed at $28.8 \mathrm{~mm}$. Changes in the relative growth rates of chelae and gonopods provided almost identical estimates of prepuberty size (28 and $28.8 \mathrm{~mm}$, respectively). It is noticeable that allometric growth was positive before the inflection point 
Table 3 Results of biometric relations obtained for Grapsus grapsus and allometric level of each equation

\begin{tabular}{|c|c|c|c|c|c|c|c|c|}
\hline \multirow[t]{2}{*}{ Biometric relation } & \multirow[t]{2}{*}{ Sex } & \multirow[t]{2}{*}{ Category } & \multirow[t]{2}{*}{$n$} & \multirow[t]{2}{*}{ Equation $\left(y=a x^{b}\right)$} & \multirow[t]{2}{*}{$R^{2}$} & \multirow{2}{*}{$\begin{array}{l}\text { Allometric } \\
\text { level }\end{array}$} & \multicolumn{2}{|c|}{ Somerton's $F$ test* } \\
\hline & & & & & & & $F$ value & Cut-off (mm) \\
\hline \multirow[t]{3}{*}{$\mathrm{PL} \times \mathrm{CW}$} & \multirow[t]{3}{*}{ M } & Immature & 74 & $\mathrm{PL}=0.544 \mathrm{CW}^{0.91}$ & 0.94 & - & 36.11 & 28.0 \\
\hline & & Prepubertal & 228 & $\mathrm{PL}=0.214 \mathrm{CW}^{1.19}$ & 0.96 & + & 63.84 & 51.4 \\
\hline & & Pubertal & 68 & $\mathrm{PL}=0.0179 \mathrm{CW}^{1.82}$ & 0.90 & +++ & & \\
\hline \multirow[t]{2}{*}{$\mathrm{GL} \times \mathrm{CW}$} & \multirow[t]{2}{*}{ M } & Immature & 78 & $\mathrm{GL}=0.0125 \mathrm{CW}^{1.94}$ & 0.95 & ++++ & 532.17 & 28.8 \\
\hline & & Prepubertal & 296 & $\mathrm{GL}=0.398 \mathrm{CW}^{0.91}$ & 0.96 & - & & \\
\hline \multirow[t]{3}{*}{$\mathrm{AW} \times \mathrm{CW}$} & \multirow[t]{3}{*}{$\mathrm{F}$} & Immature & 52 & $\mathrm{AW}=0.119 \mathrm{CW}^{1.37}$ & 0.98 & ++ & 27.42 & 23.8 \\
\hline & & Prepubertal & 87 & $\mathrm{AW}=0.0314 \mathrm{CW}^{1.80}$ & 0.94 & +++ & 769.91 & 33.8 \\
\hline & & Pubertal & 176 & $\mathrm{AW}=0.777 \mathrm{CW}^{0.96}$ & 0.97 & 0 & & $* *$ \\
\hline
\end{tabular}

$P L$ chelae propodus length, $C W$ carapace width, $G L$ first gonopod length, $A W$ width of the fifth female abdominal somite

- negative, + positive, 0 isometry

* Inflection point estimated in Mature 1 analyses $(P<0.01)$, except ** where Mature 2 was used
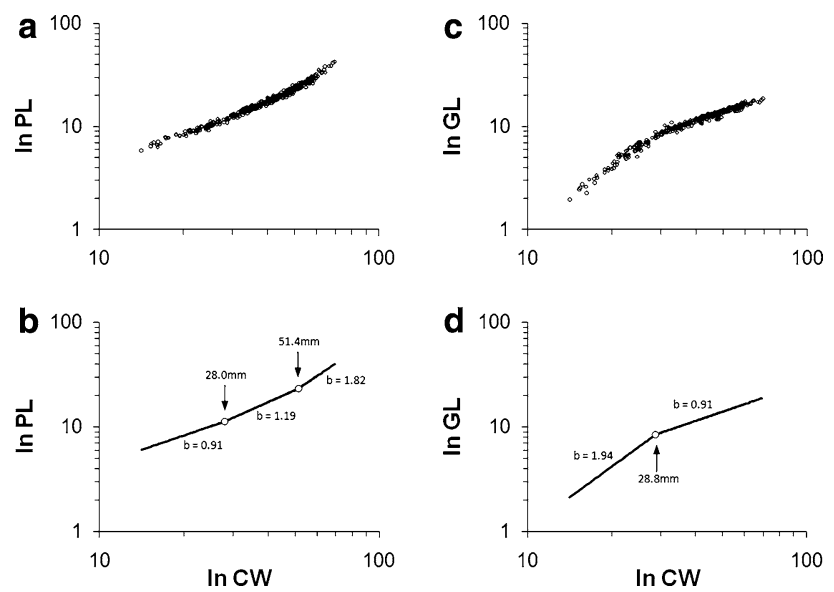

Fig. 3 Regression analysis of $\mathbf{a}$ and $\mathbf{b}$ chelar propod length (PL) $(n=370)$ and $\mathbf{c}$ and $\mathbf{d}$ first gonopod length (GL) $(n=376)$ against carapace width $(\mathrm{CW})$ for males

$(28.8 \mathrm{~mm})$ for the $\mathrm{GL} \times \mathrm{CW}$ relation but negative before the inflection point $(28 \mathrm{~mm}$ ) for the $\mathrm{PL} \times \mathrm{CW}$ relation.

For the females, the relation $\mathrm{AW} \times \mathrm{CW}$ was expressed by three different regressions: (1) $\mathrm{CW}<23.8 \mathrm{~mm}$; (2) $23.8 \leq \mathrm{CW}<39.4 \mathrm{~mm}$; and (3) $\mathrm{CW} \geq 33.8 \mathrm{~mm}$. The inflection point between regression lines 1 and $2(23.8 \mathrm{~mm})$ was considered the prepuberty size, and the positive allometric constant increased from the lower line towards the upper one (MATURE 1). MATURE 2 was used for the 29.9-39.4 mm CW zone, due to overlap between regression lines in this case. The lower line was the upper one from the previous data $(b=1.80)$, changed to negative allometric growth (0.96) after $33.8 \mathrm{~mm}$. The prepuberty size for morphological maturity was very near between sexes (males, $28.8 \mathrm{~mm}$; females, $23.8 \mathrm{~mm}$ ), but puberty moult took place at a considerably larger size in males $(51.4 \mathrm{~mm})$ than in females $(33.8 \mathrm{~mm})$.
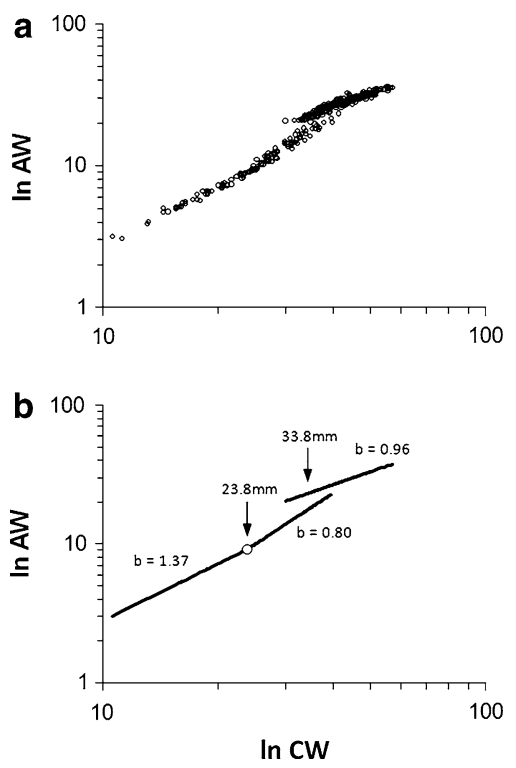

Fig. 4 Regression analysis of abdomen width (AW) against carapace width $(\mathrm{CW})$ for females $(n=315)$

Physiological maturity estimation

Among the females, $44 \%$ had gonads in the developing stage and 20\% had mature gonads. Most of the ovigerous females $(77 \%)$ had gonads in the developing stage, and none were observed with immature gonads. Among the males, the general proportion of gonadal stages was very similar, with $45 \%$ in the developing stage (DE) and $25 \%$ having mature gonads (MA). Crabs with mature gonads were found in all months sampled.

Onset of physiological maturity occurs since $20-25 \mathrm{~mm}$ $\mathrm{CW}$ class, where individuals with mature gonad were represented by $3.7 \%$ (males) and 3\% (females), reaching 50\% with 38.4 and $33.4 \mathrm{~mm}$, respectively (Fig. 5). 


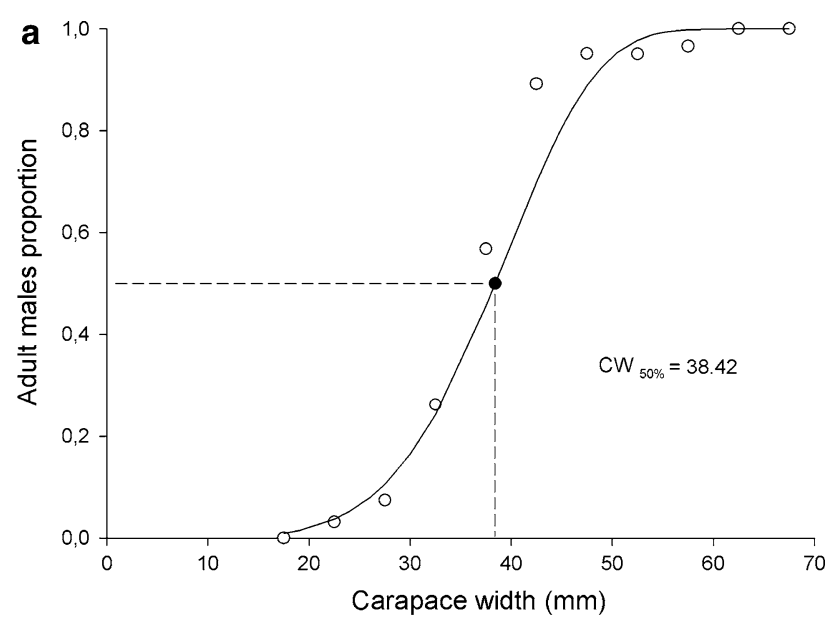

Table 4 Range of CW (carapace width, mm) within each abdomen shape category in Grapsus grapsus females

\begin{tabular}{|c|c|c|c|c|c|c|c|}
\hline \multirow[t]{2}{*}{ Abdomen shape } & \multirow{2}{*}{$\begin{array}{l}\text { Initial } \\
\mathrm{CW}\end{array}$} & \multirow{2}{*}{$\begin{array}{l}\text { Final } \\
\mathrm{CW}\end{array}$} & \multirow[t]{2}{*}{$n$} & \multicolumn{2}{|c|}{ Juveniles* } & \multicolumn{2}{|c|}{ Adults* } \\
\hline & & & & $n$ & $\%$ & $n$ & $\%$ \\
\hline Triangular & 9.1 & 34.7 & 92 & 90 & 73.8 & 2 & 1.0 \\
\hline Triangular/round & 21.2 & 48.9 & 28 & 20 & 16.4 & 8 & 4.1 \\
\hline Round & 24.1 & 57.3 & 198 & 12 & 9.8 & 186 & 94. \\
\hline Total & 9.1 & 57.3 & 318 & 122 & 100 & 196 & 100 \\
\hline
\end{tabular}

$T$ triangular, $T R$ triangular/round, $R$ round

* Calculated using morphological maturity size $(\mathrm{CW}=33.8 \mathrm{~mm})$ as parameter
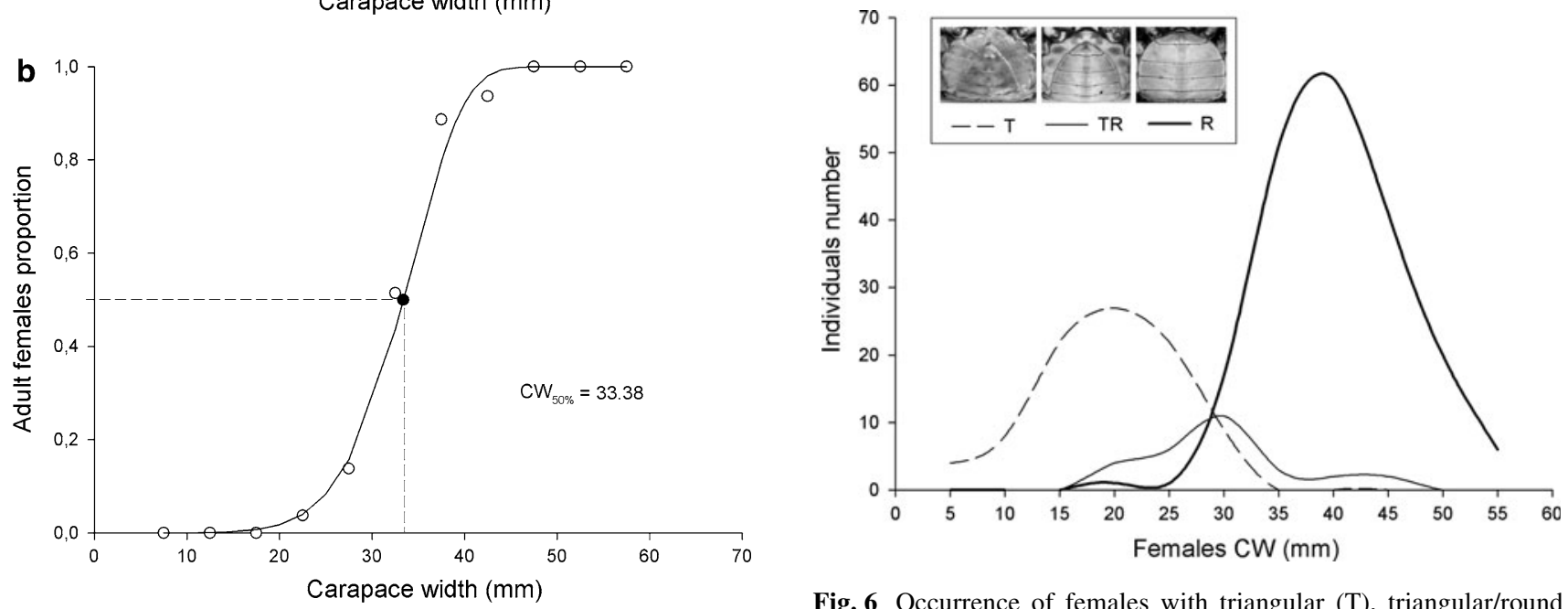

Fig. 5 Physiological maturity curve for males (a) and females (b) of Grapsus grapsus, adjusted to the empirical points of the total adult (developing and mature gonads) in each size class (black point $=\mathrm{CW} 50 \%=$ size at which half the population is sexually mature)

Morphology of the female abdomen

There was a clear trend for abdominal shape change from triangular to round as $\mathrm{CW}$ increased (Table 4; Fig. 6). Females with triangular abdomen $(1 \%)$ were found above the size of morphological maturity $(33.8 \mathrm{~mm})$, while $6 \%$ of females with round abdomen were registered below that size. The transition of the specimens with three abdominal shapes corresponds to overlap between the two upper regression lines for the biometric relation $\mathrm{AWxCW}$ $(29.9 \leq \mathrm{CW}<39.4 \mathrm{~mm})$.

\section{Carapace colour}

The distribution of colour pattern according to the size of each sex indicated a general trend towards shift from the green pattern to the red one according to the size increment $(n=522)$ (Fig. 7). Red crabs were mainly large males,

Fig. 6 Occurrence of females with triangular $(\mathrm{T})$, triangular/round (TR) and round (R) abdomens, by carapace width (CW)

while green crabs were small specimens (not sex dependent). Females of all colours were recorded above the size of sexual maturity $(33.8 \mathrm{~mm})$. Crabs of intermediate size $(35-45 \mathrm{~mm})$ had all colour patterns. Few male crabs reached physiological maturity $(38.4 \mathrm{~mm})$ with the green pattern. Morphological sexual maturity in males $(51.4 \mathrm{~mm})$ was achieved when the crabs already had red legs, a red frontal carapace plate or were fully red.

Mutilated crabs

From a total of 522 crabs, $122(24 \%)$ were recorded with scars, holes, missing limbs and regenerating bourses. Crabs were recorded with perforations in the carapace and even with the whole branchial chamber exposed. Missing pereiopods were registered in 119 crabs (Table 5). Most of them (68.9\%) had one missing pereiopod, but crabs with 3 or 4 missing pereiopods were also observed wandering over the rocks. Some crabs had the pereiopod removed in both sides; the fourth pereiopod was the most removed one (Fig. 8). 


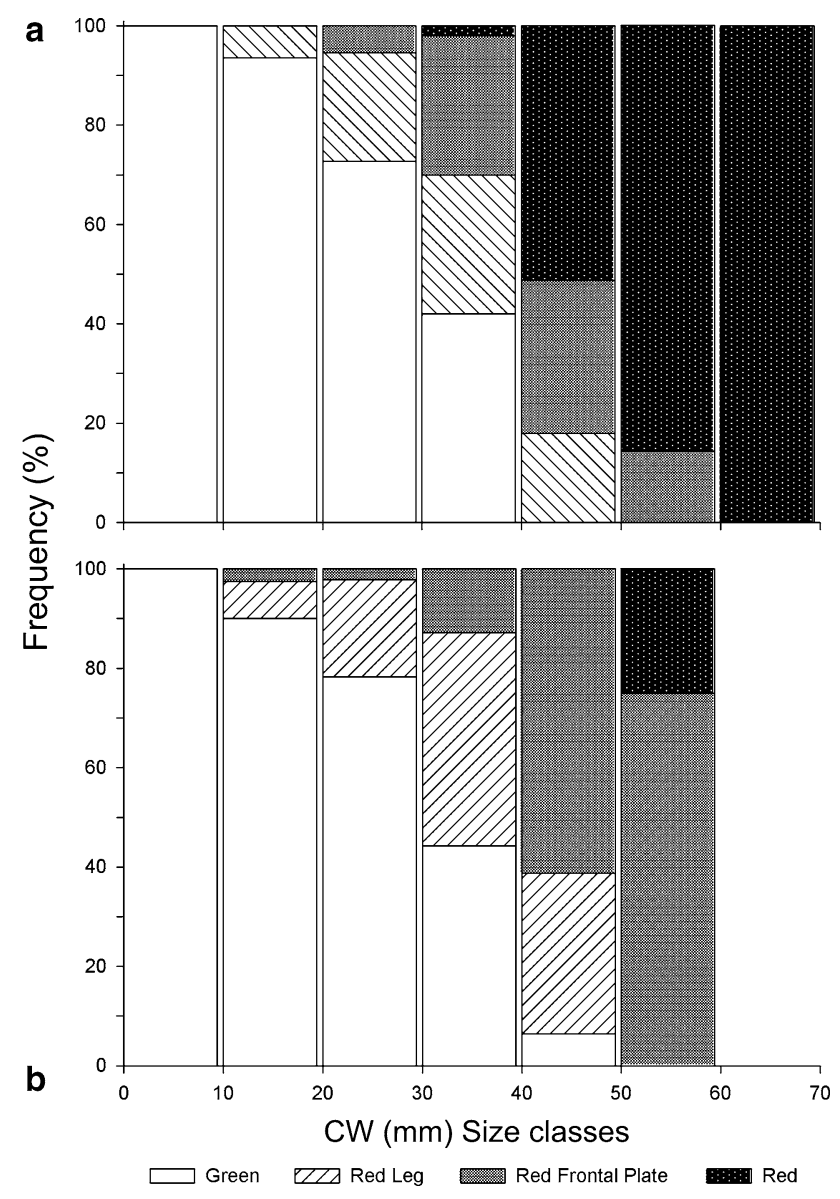

Fig. 7 Occurrence of different colour patterns on Grapsus grapsus by carapace width (CW) a males b females

Table 5 Number of crabs with missing limbs (from 1 to 4) and register of the missing pereiopods in Grapsus grapsus

\begin{tabular}{|c|c|c|c|}
\hline No. of missing limbs & \multicolumn{2}{|c|}{$n$} & $\%$ \\
\hline 1 & \multicolumn{2}{|c|}{82} & 68.9 \\
\hline 2 & \multicolumn{2}{|c|}{31} & 26.1 \\
\hline 3 & \multicolumn{2}{|c|}{5} & 4.2 \\
\hline 4 & \multicolumn{2}{|c|}{1} & 0.8 \\
\hline Total & \multicolumn{2}{|c|}{119} & 100 \\
\hline Missing pereiopod & One side & $\mathrm{R}$ and $\mathrm{L}$ & $\%$ \\
\hline $1 \mathrm{st}$ & 10 & 2 & 10.1 \\
\hline 2nd & 10 & 1 & 9.2 \\
\hline $3 r d$ & 16 & & 13.4 \\
\hline 4 th & 23 & 1 & 20.2 \\
\hline 5 th & 19 & & 16.0 \\
\hline$>1$ & 37 & & 31.1 \\
\hline
\end{tabular}

$n$ number of crabs, $R$ right, $L$ left

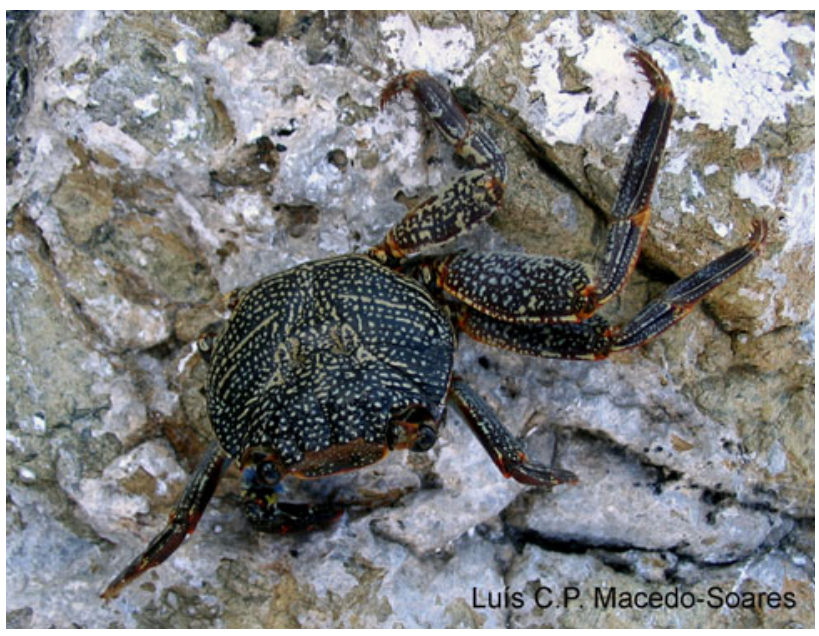

Fig. 8 Mutilated green Grapsus grapsus wandering in the rocks

Mutilated crabs were recorded in all the classes, inside the female and male size range (Fig. 9a). More than two missing pereiopods were also recorded in most of the sizes analysed (Fig. 9b). Mutilations of large males $(>60 \mathrm{~mm}$ ) were scars verified on the carapace. Males and females had equal proportions of missing limbs $\left(\chi^{2}=1.80 ; P>0.01\right)$, occurring the same when crabs without one to three pereiopods were compared $\left(\chi^{2}=3.28,0.06\right.$ and 0.60 , respectively; $P>0.01)$. Moreover, females without 4 limbs represented more than $50 \%$ of predicted $\left(\chi^{2}=4.00 ; P>0.01\right)$.

\section{Discussion}

Data about size range of Grapsus grapsus are only available for Pacific Ocean sites. The maximum sizes attained by G. grapsus from SPSPA (males, $69.5 \mathrm{~mm}$; females, $57.3 \mathrm{~mm}$ ) were smaller than recorded in Galapagos by Veintimilla (1975) (75 mm), in Mexico by Rathbun (1918) $(87 \mathrm{~mm}$ ) and in Peru by Romero (2003) (males, $79.8 \mathrm{~mm}$; females, $74.6 \mathrm{~mm}$ ). The maximum size of $G$. grapsus males sampled in this study was similar to G. adscencionalis $(67 \mathrm{~mm})$, although the females of the latter species were slight larger (69 mm) (Hartnoll 2009).

In brachyuran crabs, the size at the onset of sexual maturity using a single criterion may lead to unrealistic conclusions regarding the actual size at which these organisms are functionally mature (Flores et al. 2002). Lopez Grego and Rodrigues (1999) evidenced a great contrast between different estimates for Chasmagnathus granulatus. In the case of Perisesarma guttatum, gonadal maturity was also reached much earlier than morphological maturity, while the size of the smallest ovigerous female was surprisingly large, closer to maturity size by biometry (Flores et al. 2002). Estimates 

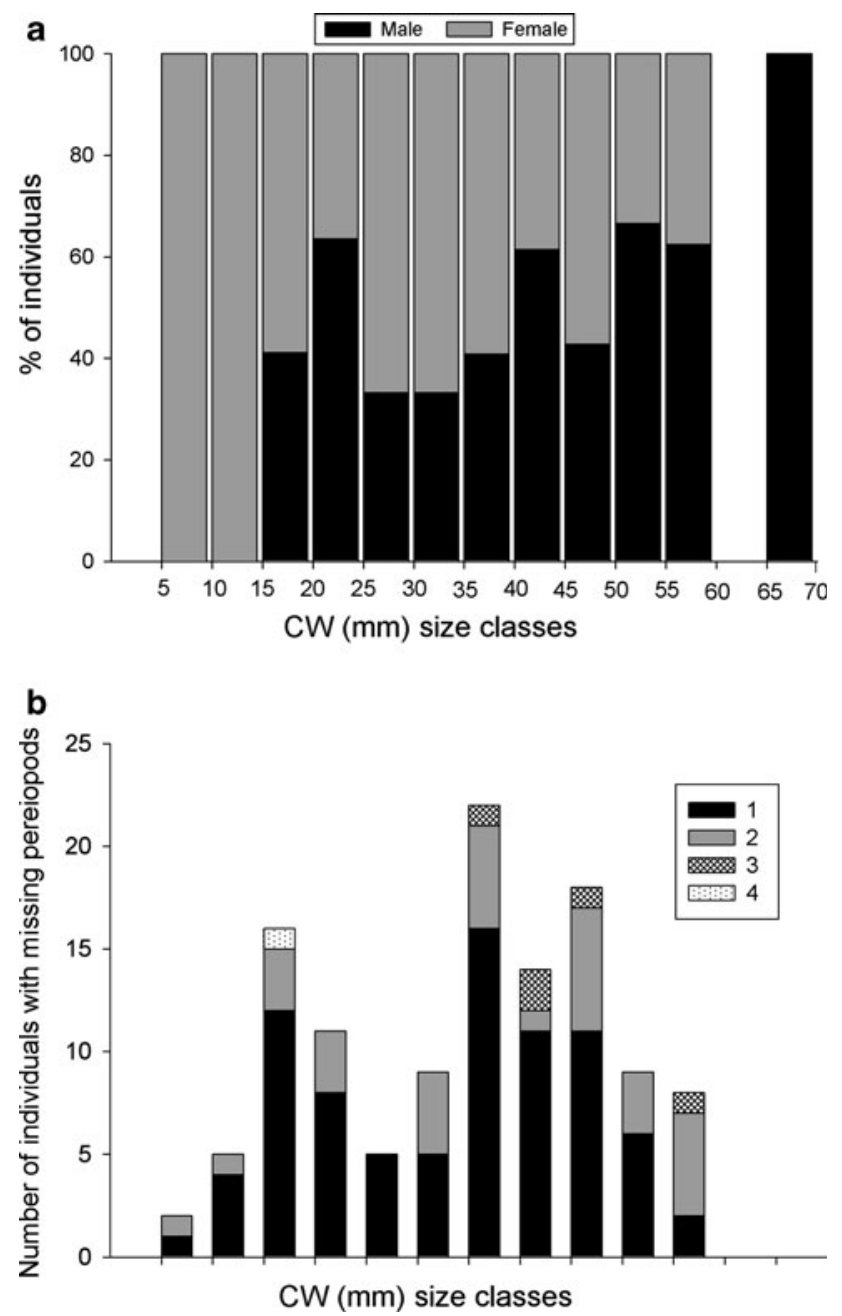

Fig. 9 Mutilation in G. grapsus by size class (CW, carapace width): a Percentage of injured crabs (injured carapace, missing limbs or regenerating bourse) in females and males and $\mathbf{b}$ number of crabs with 1-4 missing limbs in both sex

based on the smallest ovigerous crab are dependent on sample size and the ovigerous state and do not be used alone to estimate mature specimens (Flores and Paula 2002).

Females of $G$. grapsus with three different shapes of abdomen could be found within the range of the morphological maturity size. In grapsoid crabs, when the abdomen reaches the basis of pereiopod coxae (maximum $\mathrm{AW}$ ), the female is considered morphologically mature; in Chasmagnathus granulatus, at least two moults were necessary to complete morphological maturation of the abdomen (Luppi et al. 2004), with some females observed carrying eggs after first moult, although this sex became morphologically mature when the abdomen is clearly wider and rounded (Luppi et al. 2004).

In G. grapsus, the prepuberty size $(23.8 \mathrm{~mm})$ was reached concurrently during transition to the round abdominal shape $(21.2-24.1 \mathrm{~mm})$. Female crabs from 23.8 to
$33.8 \mathrm{~mm}$ (with intermediate abdomen shape) could be designated as adolescent (or prepuberal), according to the terminology adopted by Alunno-Bruscia and Sainte-Marie (1998) and Luppi et al. (2004); however, only after $39.4 \mathrm{~mm}$, females were invariably adults.

Only $5.6 \%$ of the 90 females with smaller sizes than the overlap between the prepuberal and puberal phases $(<31.6 \mathrm{~mm})$ had developing and mature gonads. In the overlap of these two upper regression lines (31.6-36.8 mm) occurs 47 specimens that comprise $19(40.4 \%)$ prepuberal and $28(59.6 \%)$ adults, whereas $74.5 \%$ (35 females) had functional maturity. In sizes greater than the overlap (>36.8 mm), only seven females $(4.2 \%)$ of 165 specimens showed no functional maturity. Ovigerous females were registered since $31.6 \mathrm{~mm}$ and comprise a good estimate of the onset of functional maturity of G. grapsus in this study. In Galapagos, most of the G. grapsus ovigerous females ranged from 36 to $45 \mathrm{~mm} \mathrm{CW}$ (Veintimilla 1975), reinforcing our results for female adult size in this species. Sexual maturity of G. adscencionalis was also reached at a similar size (Hartnoll 2009).

Defining size at the onset of functional maturity is more difficult in males because there is increasing evidence that males bearing fully developed testes may be prevented from mating (Flores and Paula 2002). According to the Flores et al. (2002), the high positive allometric growth of the gonopods can be explained by the distinct development of pleopods into functional gonopods, the same occurring with exemplars of G. grapsus with $\mathrm{CW}<28.8 \mathrm{~mm}$. After that size, gonopods growth became negatively allometric; the crabs allocated their energy to increasing their chelae, confirmed by positive allometric growth of propodus length. Chelipeds are used in territorial defence, combat, display and courtship (Hartnoll 1982). The continuous increase in the positive allometric growth of the chelae, even after the $51.4 \mathrm{~mm}$ (cut-off point), indicates that enlargement of the chelipeds is essential to functional maturity. The onset of gonadal maturation in males occurs since $24.2 \mathrm{~mm}$, all being morphologically immature until $51.4 \mathrm{~mm}$ (size of morphological maturity), with $47.2 \%$ of them showing developing and mature gonadal stages. From $51.4 \mathrm{~mm}$, $96.2 \%$ of individuals have mature gonads and were morphologically and physiologically suitable for reproduction (functional maturity). Male physiological maturity of G. adscencionalis $(32-36 \mathrm{~mm})$, established by Hartnoll (2009), was similar to G. grapsus, and they also exhibited higher allometric growth of chelae among larger crabs.

After $50 \mathrm{~mm}$, the proportion of red males increased in the population, indicating that maturity is also related to this colour pattern change. Male crabs from 38.4 to $51.4 \mathrm{~mm}$ had functional gonopods and were physiological mature, but their proportional chelae size made them less able to compete with the red males. In fact, red frontal plate 
males could be seen copulating in the rocks when the breeding embrace took place far from the fully red males. In grapsoids, size differences between potentially mature males may be quite high and exclusion of juvenile crabs during agonistic interactions is expected (Flores et al. 2002). Males were larger than females in all mating pairs observed, which was caused by the size of males at functional maturity being greater than female ones. Mating couples involving a larger male and a smaller female are commonly recorded in brachyuran crabs (e.g. Pinheiro and Fransozo 1999; Flores and Paula 2002), and small males are also under risk of being predated by the female (Lopez Grego and Rodrigues 1999). Cannibalism was observed in a G. grapsus Peruvian population after the copula, resulting in the death of the male (Romero 2003), which was not seen at the site studied by us.

In many marine crabs, phenotypic plasticity in carapace colouration patterns has been observed (Reuschel and Schubart 2007) and may involve some advantage against visual predators (Todd et al. 2005). Colouration patterns in semi-terrestrial crabs may change with growth, seasonality, current state of the individual such as stress, endogenous rhythms and even changes in temperature (Silbiger and Munguia 2008). Carapace colour has been also correlated with respiratory and osmoregulatory physiology, response to desiccation, moult cycle, chelae biometry/prey selection, chelae autotomy and mating behaviour (Reid et al. 1997).

The fact that mature Grapsus grapsus males had at least some red colour in their carapace indicated that this colour pattern was important in mating behaviour. Most of the time we observed red leg and red frontal plate male crabs interested in the same female, and the fully red ones could displace them. Colour and size has already been considered representative of hierarchy status in other male grapsoid crabs (reviewed in Abello et al. 1997). The existence of relation between colour, size and sex was described in Perisesarma (Huang et al. 2007) and Heloecius cordiformis (Detto et al. 2004).

In Xantho poressa, the different colour patterns of juveniles and adults are still controversial. Bedini (2002) suggested that the juveniles have colour patterns that conform to cryptic mimicry in sea grass and that the adults change their colour at their final moult to complete adulthood and move to rocky shores. However, Reuschel and Schubart (2007) argued that both juveniles and adults were found with highly variable colours, suggesting that they use different colours and disruptive cryptic colouration as passive defence (camouflage). In the SPSPA, green-grey G. grapsus were manly found at sea level, on vertical and negative rocky walls, well camouflaged against the dark rocks. On the other hand, the fully red crabs were proportionally more abundant in the rocky pools, nesting bird sites and protected horizontal rocks. Carcinus maenas also had a single colour form dominating in a particular area, but the extensive review of Reid et al. (1997) was unable to elucidate the reason. The change in allometric growth of Grapsus grapsus near to the size at which fully red crabs were proportionally more abundant was related to the fact that larger and red crabs had wider and more circular carapaces than green ones. Changes in allometric growth were also associated with changes to the carapace shape of $X$. poressa (Reuschel and Schubart 2007).

Females of Grapsus grapsus in Galapagos also changed their colour gradually from black to red as size increased, reinforcing the popular belief that the larger and redder the crabs are, the more mature they are (Veintimilla 1975). In the SPSPA, red males of G. grapsus were more successful in mating, but males with some green in the carapace were also sexually mature. The colour pattern did not seem to be very important for female breeding success, since sexually mature and ovigerous females of all colours were found.

The aggressive intraspecific behaviour of the fully red crabs was even observed when the green crabs were simply walking nearby and not only related to breeding competition. The encounter was usually followed by autotomy and escape or by the death and consumption of the smaller crab. Smaller victims reduce the risk to predators and reduce handling time, making the prey item more profitable in terms of energy returns (Kurihara and Okamoto 1987). Data on injured crabs within a population are very variable in the literature (9-65\%) (review by Davis et al. 2005). Cannibalism, expressed by the mutilation index, among G. grapsus in the SPSPA (24\%) was much higher than in Peru (5\%) (Romero 2003). Cannibalism is a common phenomenon amongst crustaceans and certain conditions encourage this behaviour: an unusual small habitat that prevents dispersal and promotes high population densities (Moller et al. 2008), limited food and little available refuge (Marshall et al. 2005). All of these conditions were present in our site, but we do not know which factors contributed to the high mutilation rate. A high percentage of crabs with only one missing limb, a slightly smaller percentage of missing chela, both sexes equally mutilated and large males with scars were also observed in Peruvian G. grapsus (Romero 2003). The impact of limb losses may indirectly affect other parameters, such as habitat choice and distribution (Davis et al. 2005) and the growth and structure of crab populations (Luppi et al. 2001). If a rocky intertidal crab is unable to negotiate its habitat as well with missing walking legs, it may choose an area less influenced by tidal energy until its limbs regenerate (Davis et al. 2005). The negative effects of mutilation on growth have been described in other crab species, and limb regeneration may affect the process of morphological change at the onset of maturity (Luppi et al. 2001). Limb autotomy, especially in species with high incidence of autotomies, should be considered in crab 
fisheries where size at the onset of maturity is relevant (Luppi et al. 2001).

The environmental conditions at the SPSPA are unique, due to the low diversity of food items, lack of predators for large crabs and high degree of geographic isolation. On other Brazilian oceanic islands, G. grapsus feed on newborn turtles, while on the Peruvian coast the species preys on cirripeds and mytilideans mussels (Romero 2003), all of which are absent at our site. However, the booby Sula leucogaster colony represents an important food source for the crab, contributing to the high abundance of crabs in relation to other sites (Gianuca and Vooren 2007). These features, together with the high mutilation rate, can affect functional maturity size. Future work on reproduction and behaviour on the Brazilian oceanic islands should take account of the contribution of the environment to the definition of maturity. Molecular, morphological, biometric and carapace colour studies will clarify the status of this species in the Atlantic Ocean islands, as well as the connectivity between its populations.

Acknowledgments This research was supported by Conselho Nacional de Desenvolvimento Científico e Tecnológico (CNPq) (Grant 48.0040/2004-4 and 55.8470/2005-0) and Comissão Interministerial para os Recursos do Mar (CIRM). We would like to thank the crew of the fishing boats Transmar I and Transmar II and all the biologists, aquaculture engineers and oceanographers who helped during the field work and crab biometry, especially Vanessa Bevilacqua Tomin Borges for initial data sampling and analysis. We would like to thank Luis Carlos P. Macedo-Soares and Matheus M. Coelho (ECZ/ UFSC) for the help with the maps and graphs.

\section{References}

Abello P, Aagaard A, Warman CG, Depedge MH (1997) Spatial variability in the population structure of the shore crab Carcinus maenas (Crustacea: Brachyura) in a shallow-water, weakly tidal fjord. Mar Ecol Prog Ser 147:97-103

Alunno-Bruscia M, Sainte-Marie B (1998) Abdomen allometry, ovary development, and growth of female snow crab, Chionoecetes opilio (Brachyura, Majidae), in the northwestern Gulf of St Lawrence. Can J Fish Aquat Sci 55:459-477

Bedini R (2002) Colour change and mimicry from juvenile to adult: Xantho poressa (Olivi, 1792) (Brachyura, Xanthidae) and Carcinus maenas (Linnaeus, 1758) (Brachyura, Portunidae). Crustaceana $75: 703-710$

Corgos A, Freire J (2006) Morphometric and gonad maturity in the spider crab Maja brachydactyla: a comparison of methods for estimating size at maturity in species with determinate growth. ICES J Mar Sci 63:851-859

Davis JLD, Dobroski NA, Carlton JT, Prevas J, Parks S, Hong D, Southworth E (2005) Autotomy in the Asian Shore Crab (Hemigrapsus sanguineus) in a non-native area of its range. J Crust Biol 25:655-660

Detto T, Zeila J, Magrath RD, Hunt S (2004) Sex, size and colour in a semi-terrestrial crab, Heloecius cordiformis (H. Milne Edwards, 1837). J Exp Mar Biol Ecol 302:1-15

Edwards A, Lubbock R (1983) Marine zoogeography of St Paul's Rocks. J Biogeogr 10:65-72
Feitoza BM, Rocha LA, Júnior OJL, Floeter SR, Gasparini JL (2003) Reef fishes of St. Paul's Rocks: new records and notes on biology and zoogeography. Aqua J Ichthyol Aquatic Biol 7:61-82

Flores AV, Paula J (2002) Sexual maturity, larval release and reproductive output of two brachyuran crabs from a rocky intertidal area in central Portugal. Invertebr Reprod Dev 42:21-34

Flores AV, Saraiva J, Paula J (2002) Sexual maturity, reproductive cycles, and juvenile recruitment of Perisesarma guttatum (Brachyura: Sesarmidae) at Ponta Rasa mangrove Swamp, Inhaca Isalnd, Mozambique. J Crust Biol 22:143-156

Fonteles-Filho AA (1989) In: Fonteles-Filho AA (ed) Recursos pesqueiros. Biologia e dinâmica populacional. Ceará, Fortaleza

Freire AS, Pinheiro MAA, Madeira K, Teschima MM, Silva H, Koettker AG, Fonseca DB (2009) A vida do caranguejo Grapsus grapsus (Linnaeus, 1758) no Arquipélago de São Pedro e São Paulo. In: Viana DL, Hazin FHV, Souza MAC (orgs) O Arquipélago de São Pedro e São Paulo: 10 anos de Estação Cientifica. Brasilia, DF, SECIRM, pp 195-204. ISBN: 978-85.62033-00-1

Gianuca D, Vooren CM (2007) Abundance and behavior of the sally lightfoot crab Grapsus grapsus in the colony of the brown booby (Sula leucogaster) in the São Pedro and São Paulo archipelago. Invest Mar 35:121-125

Guerao G, Schubart CD, Cuesta JA (2001) The first zoeal stages of Grapsus grapsus (Linnaeus) and Geograpsus lividus (H. Milne Edwards) (Decapoda, Brachyura, Grapsidae) from the Western Atlantic. Nauplius 9:111-121

Hartnoll RG (1963) The biology of manx spider crabs. Proc Zool Soc Lond 141:423-496

Hartnoll RG (1982) Growth. In: Bliss DE (ed) The biology of crustacea. Embryology, morphology and genetics. Academic Press, New York

Hartnoll RG (1985) Growth, sexual maturity and reproductive output. In: Wenner AM (ed) Factors in adult growth. A.A. Balkema, Rotterdam

Hartnoll RG (2001) Growth in crustacea-twenty years on. Hydrobiologia 449:111-122

Hartnoll RG (2006) Reproductive investment in Brachyura. Hydrobiologia 557:31-40

Hartnoll RG (2009) Sexual maturity and reproductive strategy of the rock crab Grapsus adscensionis (Osbeck, 1765) (Brachyura, Grapsidae) on Ascension Island. Crustac Int J Crustac Res 82:275-291

Hartnoll RG, Gould P (1988) Brachyuran life history strategies and the optimization of egg production. Symp Zool Soc Lond 59:1-9

Huang H, Todd PA, Yeo DCJ (2007) Inter- and intra-specific variation in the facial colours of Perisesarma eumolpe and Perisesarma indiarum (Crustacea: Brachyura: Sesarmidae). Hydrobiologia 598:361-371

Koettker AG, Freire AS, Sumida PYG (2009) Temporal, diel and spatial variability of decapod larvae from St Paul's Rocks, an Equatorial Oceanic Island of Brazil. J Mar Biol Assoc UK 89:1-13

Kurihara Y, Okamoto K (1987) Cannibalism in a grapsid crab Hemigrapsus penicillatus. Mar Ecol Prog Ser 41:123-127

Lopez Grego LS, Rodrigues EM (1999) Size at the onset of sexual maturity in Chasmagnathus granulatus Dana, 1851 (Grapsidae, Sesarminae), a critical overall view about the usual criteria for its determination. In: Schram FR, VonVaupel Klein JC (eds) Crustaceans and the biodiversity crisis. Brill, Leiden

Luppi TA, Spivak ED, Anger K (2001) Experimental studies on predation and cannibalism of the settlers of Chasmagnathus granulata and Cyrtograpsus angulatus (Brachyura: Grapsidae). J Exp Mar Biol Ecol 265:29-48

Luppi TA, Spivak ED, Bas CC, Anger K (2004) Molt and growth of an estuarine crab, Chasmagnathus granulatus (Brachyura:Varunidae), in Mar Chiquita coastal lagoon, Argentina. J Appl Ichthyol 20:333-344 
Madeira KC (2008) Crescimento e densidade populacional do caranguejo Grapsus grapsus (Linnaeus, 1758) no Arquipélago de São Pedro e São Paulo. MS Dissertation, Fundação Universidade Federal do Rio Grande, Rio Grande, RS

Manning RB, Chace FA Jr (1990) Decapod and stomatopod crustacea from ascension Island, South Atlantic Ocean. Smithson Contrib Zool 503:1-91

Marshall S, Warburton K, Paterson B, Mann D (2005) Cannibalism in juvenile blue-swimmer crabs Portunus pelagicus (Linnaeus, 1766): effects of body size, moult stage and refuge availability. Appl Anim Behav Sci 90:65-82

Moller H, Lee SY, Paterson B, Mann D (2008) Cannibalism contributes significantly to the diet of cultured sand crabs, Portunus pelagicus (L.): A dual stable isotope study. J Exp Mar Biol Ecol 361:75-82

Pinheiro MAA, Fiscarelli AG (2001) In: Pinheiro MMA (ed) Manual de Apoio à Fiscalização do Caranguejo-Uçá (Ucides cordatus). Cepsul, Itajaí

Pinheiro MAA, Fransozo A (1998) Sexual maturity of the speckled swimming crab Arenaeus cribbarius (Lamarck, 1818) (Decapoda, Brachyura, Portunidae) in the Ubatuba Littoral, São Paulo State, Brazil. Crustac Int J Crustac Res 71:434-452

Pinheiro MAA, Fransozo A (1999) Reproductive behavior of the swimming crab Arenaeus cribrarius (Lamarck, 1818) (Crustacea, Brachyura, Portunidae) in captivity. Bull Mar Sci 64:243-253

Pinheiro MAA, Fransozo A (2002) Reproductive dynamics of the speckled swimming crab Arenaeus cribrarius (Lamarck, 1818) (Brachyura, Portunidae), on the north coast of São Paulo State, Brazil. J Crust Biol 22:416-428

Rathbun MJ (1918) Synopsis of the American Sesarmae, with description of a new species. Proc Biol Soc Wash 11:89-92

Ratti AP (2004) Taxonomia e Biogeografia da Superfamília Grapsoidea MacLeay (excl. Gecarcinidae) (Crustacea: Decapoda: Brachyura) do Atlântico Ocidental. PhD thesis, Instituto de Biociências, Universidade de São Paulo, São Paulo, SP
Reid DG, Abello P, Kaiser MJ, Warman CG (1997) Carapace Colour, Inter-moult Duration and the Behavioural and Physiological Ecology of the Shore Crab Carcinus maenas. Estuar Coast Shelf Sci 44:203-211

Reuschel S, Schubart CD (2007) Contrasting genetic diversity with phenotypic diversity in coloration and size in Xantho poressa (Brachyura: Xanthidae), with new results on its ecology. Mar Ecol 28:296-305

Romero L (2003) Comportamiento reproductivo y mutilaciones en el cangrejo de las rocas Grapsus grapsus (Linnaeus, 1758) (Crustacea, Decapoda). Rev Per Biol 10:195-202

Schejter L, Spivak E (2005) Morphometry, sexual maturity, fecundity and epibiosis of the South American spider crab Libidoclaea granaria (Brachyura: Majoidea). J Mar Biol Ass UK 85: 857-863

Silbiger N, Munguia P (2008) Carapace color change in Uca pugilator as a response to temperature. J Exp Mar Biol Ecol 355:41-46

Somerton DA (1980) A computer technique for estimating the size of sexual maturity in crabs. Can J Fish Aquat Sci 37:1488-1494

Somerton DA, Macintosh RA (1983) The size at sexual maturity of the blue king crab, Paralithoides platypus in Alaska. Fish Bull 81:621-628

Todd PA, Briers RA, Ladle RJ, Middleton F (2005) Phenotype-environment matching in the shore crab (Carcinus maenas). Mar Biol 148:1357-1367

Vaske Júnior T, Hazin FHV, Lessa RP (2006) Pesca e hábitos alimentares do peixe-rei, Elagatis bipinnulata (Quoy and Gaimard, 1825) (Pisces: Carangidae) no Arquipélago de São Pedro e São Paulo, Brasil. Arq Ciênc Mar 39:61-65

Veintimilla EMP (1975) Observaciones sobre la madurez sexual, tamaño y color de la sayapa Grapsus grapsus L. (Brachyura, Grapsidae) de la Isla Santa Cruz, Galapagos. Rev Univ Católica III 8:141-148

Zar JH (1998) Biostatistical analysis. Prentice Hall, New Jersey 